\title{
POPULATION GENETIC ANALYSIS OF BRAZILIAN PEACH BREEDING GERMPLASM ${ }^{1}$
}

\author{
LIANE BAHR THUROW ${ }^{2}$, MARIA DO CARMO BASSOLS RASEIRA ${ }^{3}$, SANDRO BONOW ${ }^{3}$, \\ LUIS WILLIAN PACHECO ARGE ${ }^{4}$, CAROLINE MARQUES CASTRO 3
}

\begin{abstract}
Peach has great economic and social importance in Brazil. Diverse sources of germplasm were used to introduce desirable traits in the Brazilian peach breeding pool, composed mainly by local selections and accessions selected from populations developed by the national breeding programs, adapted to subtropical climate, with low chill requirement, as well as accessions introduced from several countries. In this research, we used SSR markers, selected by their high level of polymorphism, to access genetic diversity and population structure of a set composed by 204 peach selected genotypes, based on contrasting phenotypes for valuable traits in peach breeding. A total of 80 alleles were obtained, giving an average of eight alleles per locus. In general, the average value of observed heterozygosity $(0.46)$ was lower than the expected heterozygosity (0.63). STRUCTURE analysis assigned 162 accessions splitted into two subpopulations based mainly on their flesh type: melting (96) and non-melting (66) flesh cultivars. The remaining accessions (42) could not be assigned under the $80 \%$ membership coefficient criteria. Genetic variability was greater in melting subpopulation compared to non-melting. Additionally, $55 \%$ of the alleles present in the breeding varieties were also present in the founder varieties, indicating that founding clones are well represented in current peach cultivars and advanced selections developed. Overall, this study gives a first insight of the peach genetic variability available and evidence for population differentiation (structure) in this peach panel to be exploited and provides the basis for genome-wide association studies.
\end{abstract}

Index terms: Prunus persica, genetic diversity, population structure, low chill germplasm, genetic resources.

\section{ESTRUTURA GENÉTICA DO GERMOPLASMA DE MELHORAMENTO DE PESSEGUEIRO NO BRASIL}

RESUMO - O pessegueiro tem grande importância econômica e social no Brasil. Diversas fontes de germoplasma foram utilizadas para a introdução de caracteres desejados no pool gênico de pessegueiro do Brasil, constituído principalmente de seleções naturalizadas e de acessos selecionados a partir de populações desenvolvidas pelos programas de melhoramento, adaptadas às condições de clima subtropical, de baixa exigência em frio, bem como acessos introduzidos de diversos países. Neste estudo, foram utilizados marcadores SSR, selecionados por seu elevado nível de polimorfismo, com o objetivo de acessar a variabilidade genética e a estrutura populacional de um painel composto por 204 genótipos de pessegueiro, selecionados com base em fenótipos contrastantes para importantes caracteres no melhoramento do pessegueiro. Um total de 80 alelos foram identificados, com média de oito alelos por loco. Em geral, o valor médio da heterozigosidade observada $(0,46)$ foi menor do que a heterozigosidade esperada $(0,63)$. Análises do STRUCTURE atribuíram 162 acessos em duas subpopulações, majoritariamente com base em caracteres relativos ao fruto: cultivares fundentes (96) e não fundentes (66). Os acessos restantes (42) foram considerados não estruturados, utilizando um coeficiente de adesão de $80 \%$. A variabilidade genética foi maior na subpopulação fundente em comparação com a não fundente. Além disso, $55 \%$ dos alelos presentes nas cultivares e seleções do programa de melhoramento também estão presentes nos clones de fundação, indicando que estes clones estão bem representados nas cultivares de pessegueiro e em seleções avançadas desenvolvidas. Este estudo apresenta uma primeira percepção da variabilidade genética disponível e evidências para a diferenciação da população (estrutura) neste painel de pessegueiro, que pode ser explorada e servir como base para estudos de mapeamento associativo.

Termos para indexação: Prunus persica, variabilidade genética, estrutura de população, germoplasma de baixo frio, recursos genéticos.

\footnotetext{
(Paper 093-16). Received July 27, 2016. Accepted December 13, 2016.

${ }^{2}$ Eng. Agr., MSc., Doutoranda do Programa de Pós-Graduação em Agronomia/Fitomelhoramento, Universidade Federal de Pelotas, Bolsista CAPES. Pelotas-RS. E-mail: lianepel@yahoo.com.br

${ }^{3}$ Eng. Agr., Dr., Pesquisador da Embrapa Clima Temperado, Pelotas-RS. E-mails: maria.bassols@embrapa.br; sandro.bonow@embrapa.br; caroline.castro@embrapa.br

${ }^{4}$ Tecg. Fruticult., Dr., Pós-doutorando do Laboratório Nacional de Computação Científica, Petrópolis-RJ. E-mail: 1.willianpacheco@gmail.com
} 


\section{INTRODUCTION}

Peach [Prunus persica (L.) Batsch] is considered an important agricultural crop worldwide, becoming the third most produced temperate tree fruit species, after apple and pear (BYRNE et al., 2012; FONT I FORCADA et al., 2013). The world production of peach and nectarine was approximately 22.8 million tons in 2014 whereas in Brazil was approximately 211 thousand tons (FAOSTAT, 2017).

Peach is native of China where it was domesticated 4,000-5,000 years ago, and later spread around the world (FAUST; TIMON, 1995). For centuries, seed propagation was the main source of plants and consequently landrace genotypes resulted from this movement. This germplasm became the base of productive hybrids adapted to a wide range of different climate regions throughout the world (BYRNE, 2005a; BIELENBERG et al., 2009).

In the Americas, peach was introduced by the Spanish and Portuguese during the sixteenth century, where it was quickly adopted by the native people and spread to a wide variety of environments (BYRNE et al., 2012). According to historical records, peach was introduced in Brazil in 1532 by Martim Afonso de Souza, through seedlings brought from Madeira Island and planted in São Vicente, where it is currently the state of São Paulo (RASEIRA; NAKASU, 2002).

In the 1950s, two breeding programs - one in São Paulo and the other in Rio Grande do Sul state - started in Brazil, aiming the development of fresh market and processing peach cultivars adapted to mild winter regions. Local cultivars were then used as founding clones and had great importance for the breeding programs. All this germplasm probably arrived in Brazil several hundred years ago. Since this initial material was propagated by seed, only the most productive and adapted genotypes were maintained. In this way, locally adapted peaches were developed (BYRNE, 2003). Among them it should be cited the non-melting varieties 'Aldrighi', 'Ambrosio Perret', 'Abóbora', and 'Intermediário', used mainly in the breeding program for processing cultivars and 'Delicioso', 'Precoce Rosado', 'Admirável', and '15 de Novembro', local cultivars used intensively in southern Brazil breeding program for development of fresh market peach cultivars (BYRNE; BACON, 1999). The low chill germplasm composed initially by local varieties and seedlings selections of them was enriched by pollen and seeds (both resulted from crosses or open pollination) from the North American breeding programs and composed the basic genetic material for the Southern Brazil breeding program
(RASEIRA et al., 2008a).

The peach germplasm available in Brazil is maintained in the Active Germplasm Bank of stone fruit by Embrapa Temperate Climate, in Pelotas (coordinates $31^{\circ} 40^{\prime} 47^{\prime} \mathrm{S} 52^{\circ} 26^{\prime} 24^{\prime \prime} \mathrm{W}$ ). The origin of this germplasm is diverse, including breeding programs of Embrapa and of the Agronomic Institute of Campinas, introductions from other Brazilian states and old cultivars as well as introductions from countries such as Bolivia, Spain, USA, Italy, Canary Islands, Mexico and Japan (RASEIRA et al., 2008b).

Previous studies, mainly of morphological and phenological characterization, evidenced a high variability among the peach accessions, available for use in breeding, mainly adapted to subtropical climate, with low chilling requirement and accessions currently used as a source of resistance to brown rot, leaf rust and bacterial leaf spot (RASEIRA et al., 2008b)

Over the last two decades, simple sequence repeat markers (SSRs) have been successfully carried out in peach to assess genetic diversity (DIRLEWANGER et al., 2002; ARANZANA et al., 2003; XIE et al., 2010; BOUHADIDA et al., 2011) and more recently, for population stratification (ARANZANA et al., 2010; CAO et al., 2012; FONT I FORCADA et al., 2013; LI et al., 2013; CHAVEZ et al., 2014), providing tools for marker-assisted selection (MAS). However, to date the available peach germplasm in Brazil is still underexplored at the molecular level.

The population structure and genetic relatedness between genotypes has a strong impact on association mapping studies, becoming the main causes of spurious associations. In cases of genotype-phenotype covariance, many markers across the genome will appear to be associated with the trait of interest, when in fact these markers simply capture the genetic relatedness among individuals (MYLES et al., 2009). For this reason, to reduce the confounding effects of complex genetic relatedness among genotypes in breeding populations, it is extremely important to correct for population structure in association mapping tests.

This research is the first attempt to assess genetic diversity, comprising a wider sampling of cultivars and advanced selections, with more informative genetic markers for current peach breeding in Brazil. In the present research, we report the genetic diversity and assess population structure of 204 peach genotypes belonging to peach germplasm bank of Brazil. These results will be useful to improve further breeding strategies and choose more reliable approaches for possible genetic 
association mapping.

\section{MATERIAL AND METHODS}

\section{Plant material}

A total of 204 peach cultivars and advanced selections [Prunus persica (L.) Batsch] from the peach breeding program of the Brazilian Agricultural Research Corporation - Embrapa, was evaluated in this study (Table 1). This set is hereafter referred as the peach association panel of Embrapa. Among the total germplasm that composes the Active Germplasm Bank and work collection of the breeding program, these selected 204 genotypes represent the genetic variability available for bacterial spot, brown rot and tolerance to abiotic stresses such as heat tolerance at the flowering stage and chilling requirement. This panel also includes eight of the founding clones of the Brazilian peach breeding program (started in 1953), in order to explore how much of their genome is represented in the current breeding. Among the founders are local varieties such as 'Aldrighi', 'Abóbora', 'Edmundo Perret', 'Delicioso', 'Cristal-Taquari', 'Interlúdio' and North American varieties such as 'Panamint' and 'Sunhigh'.

\section{DNA extraction and microsatellite genotyping}

For DNA extraction, fresh young leaves were collected and stored at $-80^{\circ} \mathrm{C}$. Genomic DNA was isolated from 0.15 to $0.20 \mathrm{~g}$ frozen leaf tissue, using procedure described by Ferreira e Grattapaglia (1998). The samples were quantitated with the Qubit ${ }^{\circledR} 2.0$ fluorometer (Life Technologies, Grand Island, NY, USA) and concentrations adjusted to 10 $\mathrm{ng} / \mu \mathrm{l}$ for PCR amplification.

The 204 peach genotypes were analyzed using 10 SSR markers: BPPCT020, BPPCT002, ВРPCТ007, ВРРCТ015, ВРРСТ014, ВРРСТ017 (DIRLEWANGER et al., 2002), pchgms (SOSINSKI et al., 2000), UDP98-407 (CIPRIANI et al., 1999), CPPCT022, and CPPCT006 (ARANZANA et al., 2002), previously developed for peach and selected from the Prunus 'Texas' almond $\times$ 'Earlygold' peach $(\mathrm{T} \times \mathrm{E})$ reference map (DIRLEWANGER et al., 2004). The loci were randomly distributed in the eight linkage groups of the peach genome and chosen on the basis of their high polymorphism and reproducibility.

The forward primer of each pair was tagged with a M13 primer sequence (5'-CACGACGTTGTAAAACGAC-3') during synthesis. Polymerase chain reactions (PCR) were performed in a total volume of $10 \mu \mathrm{l}$ containing
20 ng of genomic DNA, $5 \mu \mathrm{L}$ of $2 \mathrm{X}$ GoTaq Green Master Mix (Promega Corporation, USA), and three different primers: $1.0 \mu \mathrm{M}$ of each reverse and forward primer and $1.0 \mu \mathrm{M}$ of $\mathrm{M} 13$ primer with a fluorescent label ((-29)/IRDye 800-labeled Primer) (LI-COR Biosciences). Amplifications were conducted in a GeneAmp ${ }^{\circledR}$ PCR System 9700 (Applied Biosystems) set as following: pre-denatured at $94^{\circ} \mathrm{C}$ for $1 \mathrm{~min}$; followed by 30 cycles of $45 \mathrm{~s}$ at $94^{\circ} \mathrm{C}, 45 \mathrm{~s}$ at primer's specific annealing temperature, and $2 \min$ at $72^{\circ} \mathrm{C}$, finally extended at $72^{\circ} \mathrm{C}$ for $4 \mathrm{~min}$.

PCR amplified reactions were then diluted with sterile Milli-Q water, in a proportion 1:20, to allow a clear visualization of the amplified fragments. After, $2 \mu \mathrm{L}$ of diluted PCR reaction were added to $2 \mu \mathrm{L}$ of Blue Stop Solution (LI-COR Biosciences) and denatured at $94^{\circ} \mathrm{C}$ for $3 \mathrm{~min}$, in thermocycler described above. Denatured PCR products $(0.8$ $\mu \mathrm{L}$ ) were then loaded on $6.5 \%$ polyacrylamide gel (LI-COR Biosciences) and sized by vertical electrophoresis through a 4300 DNA Analyzer LI$\mathrm{COR}$, programmed to run for a period of $90 \mathrm{~min}$ at $1500 \mathrm{~V}$ and $40 \mathrm{~mA}$.

Fragment sizes were estimated with the 50-350 bp IRDye 800 Sizing Standard (LI-COR Biosciences) and scoring performed with Saga Generation 2 software (LI-COR Biosciences).

\section{Data analysis}

The genetic variability parameters calculated for the whole peach association panel were: number of alleles per locus $\left(N_{A}\right)$, effective number of alleles per locus $\left(N_{E}\right)$, observed heterozygosity $(\mathrm{Ho})$, expected heterozygosity $(\mathrm{He})$, and Wright's fixation index $(F)$ calculated with POPGENE software version 1.32 (YEH et al., 1997). Polymorphism information content $(P I C)$, allele frequency and number of different genotypes amplified by each marker were calculated using Powermarker 3.25 software (LIU; MUSE, 2005).

For genetic comparison between founders and breeding germplasm, all cultivars released by Embrapa breeding program, since its inception, in 1953, as well as the founders, composed a group. This group, of 81 peach and nectarine cultivars, was sub-divided according to its breeding period. Founder varieties were identified as "Pre-1960s" and cultivars released by the breeding program were classified into five groups according to their releasing decade (1960s to 2000s). To assess changes in allelic counts for each SSR locus analyzed, the total number of alleles for a given breeding period was calculated by adding the numbers of alleles present in the cultivars in that period. To detect the alleles that were lost in a given period, we calculated the number of alleles 
absent in cultivars of the period and present in the founders (Pre-1960s). Similarly, gained alleles were calculated by the number of alleles present in cultivars of the period and that were absent in the founders (Pre-1960s).

Population structure on the whole peach association panel was addressed using two different approaches. The first method based on a Bayesian clustering approach was performed on the 204 peach genotypes using STRUCTURE version 2.3.4 software (PRITCHARD et al., 2000). Twenty independent runs per $\mathrm{K}$ value were performed by setting the number of subpopulations $(\mathrm{K})$ ranging from 1 to 10. Each run started with 10,000 burn-in period followed by 100,000 Monte Carlo Markov Chain (MCMC) interactions, adopting an admixture model and correlated allele frequencies.

STRUCTURE HARVESTER software (EARL; VONHOLDT, 2012) was used for visualizing STRUCTURE output and implementing the Evanno method to analyze for population stratification results (EVANNO et al., 2005).

The membership coefficients for the most optimal number of subpopulations were permuted to match the 20 replicates for that $\mathrm{K}$ value as closely as possible, using CLUMPP version 1.1.2 (JAKOBSSON; ROSENBERG, 2007). Genotypes were assigned to a subpopulation when their membership coefficient (Q) was higher than 0.8 . Results were plotted with DISTRUCT version 1.1 (ROSENBERG, 2004).

The second method to assess population structure was a factorial analysis, more specifically a Principal Coordinate analysis (PCoA) of all inferred subpopulations, based on similarity matrix, calculated using Jaccard coefficient and further construction of the 3D scatter plot using scatterplot3d package (LIGGES; MÄCHLER, 2003) performed with the R software (http://www.R-project.org).

\section{RESULTS AND DISCUSSION}

\section{Genetic diversity analysis}

In the current study, a set of 204 peach accessions were genotyped with 10 selected SSR markers distributed across the eight linkage groups of the peach genome. All loci evaluated in this study were polymorphic amplifying a total of 80 alleles, and produced a maximum of two bands per genotype, in accordance with the diploid level of this species.

An average of 8.0 alleles per locus was observed, which is higher than the values reported in previous studies on genetic diversity in peach [4.2 alleles per locus (DIRLEWANGER et al., 2002);
7.3 (ARANZANA et al., 2003); 6.36 (ARANZANA et al., 2010); 6.5 (ANDERSON, 2010); 6.73 (BOUHADIDA et al., 2011); 6.4 (CAO et al., 2012); 5.1 (FONT I FORCADA et al., 2013)].

Chavez et al. (2014) reported that a total of 237 alleles were amplified for 168 peach and nectarine cultivars and selections of the University of Florida (UF) peach germplasm using 36 SSR markers. Comparing three SSR markers (ВРPCT014, ВРPCT017 and СРPCT022) in common with their work, we were able to distinguish an average of 24 genotypes per marker while only 16 genotypes per marker were observed in UF peach germplasm. Amplified band sizes were similar to those reported by Bouhadida et al. (2011) in 94 peach cultivars including Spanish native peach and foreign commercial cultivars, however, the genetic variability parameters were lower than those observed in this study.

Our study demonstrates that 42 alleles $(52.5 \%)$ showed low frequencies (less than 5\%) including nine unique alleles detected in seven genotypes. The cultivars 'Amarillo' and 'Arlequim' presented two unique alleles each. Four unique alleles were detected in 'Tarumã', 'Springcrest', 'Natal' and 'Vila Nova', which are introductions from other countries or old cultivars, probably not used very much for breeding purposes due to some undesirable traits. 'Tarumã' is a late ripening variety, whereas 'Springcrest', an introduction used at the beginning of the breeding program, requires higher chilling hours than what accumulates in Southern Brazil. The cultivar 'Natal' has not been used in the program and 'Vila Nova' is interesting but susceptible to brown rot and bacterial spot. A unique allele was also found in a recent advanced selection of flat peaches, Cascata 1511 , originated from a cross with pollen from China.

Low allelic frequencies resulted in a low effective number of alleles $(A e)$ with an average of 3.05 representing $38.13 \%$ of the total identified alleles. The observed heterozygosity $(\mathrm{Ho})$ ranged from 0.28 (СРPCT006) to 0.62 (ВРPCT015), with an average of 0.46 . These were lower than the expected heterozygosity values $(\mathrm{He})$, which ranged between 0.50 (BPPCT002 and BPPCT007) and 0.80 (BPPCT017), with an average of 0.63. Consequently, Wright's fixation indices $(F)$ showed positive values, with a mean of 0.28 for all loci (Table 2).

Table 2 also shows that BPРCT017 had the highest polymorphism information content (PIC) of 0.77 and BPPCT002 had the lowest PIC of 0.45. The number of different genotypes identified by each marker ranged between 7 (СРPCT006) and 36 (BPPCT015), with an average of 19.8 . 
These results are also consistent with Aranzana et al. (2010), using 224 peach and nectarine cultivars from around the world, when comparing genetic variability parameters using eight SSR markers common to both studies. The estimated genetic diversity of Brazilian peach breeding germplasm was higher than reported by Aranzana's study, measures of diversity for $A$ (8.0 vs. 7.6), $\mathrm{Ae}$ (2.99 vs. 2.56 ), $\mathrm{Ho}$ (0.46 vs. 0.42$), \mathrm{He}$ (0.63 vs. 0.55$)$, respectively, and an average of 19.88 genotypes identified per marker in our study vs. 14.25 in theirs. High values of all the measures of diversity indicated allelic richness in the analyzed germplasm, which can provide additional tools for breeding. However, results from Oriental germplasm as reported in Li et al. (2013) study, using 653 peach accessions around the world amplified with 48 SSRs, showed that the estimated genetic diversity of the Brazilian peach germplasm was lower when the two studies were compared based on eight SSR markers in common: $A$ (8.0 vs. 14.5$), H o$ (0.46 vs. 0.51 ) and genotypes amplified by marker (19.87 vs. 31.75), respectively. Probably, these high values can be explained by the large sample set covering peach cultivars from Oriental and Occidental geographic regions, including wild, landraces, breeding peach accessions and peach related species. Similarly, the value of $F(0.20$ vs. 0.28$)$ was higher in Brazilian peach germplasm. The effective number of alleles per locus $A e$ (2.99 vs. 3.02) and the expected heterozygosity $\mathrm{He}(0.63$ vs. 0.64$)$ was consistent across both studies. As reported by those same authors, the Oriental accessions contributed most to the variability of the sample, especially landraces from the northwest of China, region where peach was originated. An average of 10 alleles per locus was amplified from 146 Chinese landraces. This is higher than the average of 6.4 alleles per locus reported by Cao et al. (2012), in 104 landraces distributed across six geographical regions of China analyzed with 53 SSRs and thus found an average genetic diversity of 0.567 with is lower than 0.63 found in this study.

In addition, this higher genetic variability observed in our study could be explained by the origin of germplasm sources. As these sources of low chill had generally poor commercial characteristics, they were crossed with high chill cultivars with higher commercial quality. Thus, previous studies indicate that, in general, the low chill germplasm is more diverse than the high chill USA germplasm, since it combines the high chill USA germplasm with local cultivars from Brazil and the exotic low chill southern China germplasm (BYRNE; BACON, 1999).
Among the total of 204 peach cultivars and advanced selections analyzed, the used set of 10 SSR markers enable to distinguish unambiguously 198 P. persica genotypes, with the exception of three groups with two cultivars each, which present identical genotypes. From these three groups, the first one includes the peach selections Bolinha 9 and Bolinha 17, both found with identical fingerprints and described as open pollinated seedlings of 'Bolinha'. In the second group, the selection Cascata 1423 had identical genotype as the cultivar Fascínio, probably because the selection is an open pollinated seedling from 'Fascínio'. Finally, in the third group, the cultivars Ametista and Esmeralda were described with the same molecular profiles, probably due to the first being originated from an open pollination of 'Esmeralda'. The same occurred with Aranzana et al. (2010) that used a set of 50 SSRs and were able to identify only 209 different genotypes among the 224 cultivars studied. These results demonstrate that a reduced number of informative SSR loci are efficient to genotype a peach germplasm collection and additional markers sometimes do not generate an effective increase in relevant information.

\section{Genetic comparison between founders and breeding peach germplasm}

Eight founder varieties of the Embrapa peach breeding program were studied in order to explore how much of their genome is represented in the peach breeding cultivars. We observed that 55\% of the alleles present in the breeding germplasm were also present in the founder varieties, and only $20 \%$ of these alleles shared are considered rare in the breeding varieties (it refers to alleles present at a frequency $<0.05$ ). We observed that the genetic diversity of the Embrapa germplasm panel including founder varieties did not change significantly across the decades of breeding with total number of alleles by breeding period ranged from 40 to 53 (Table 3).

There was a slight decrease in the number of alleles for cultivars released during the 1970s and 2000s than those released before the 1960s, comprising the founders of the breeding program, as well as the alleles absent when comparing to the founders, that were higher than the observed gained alleles. On the other hand, allelic counts increased during the 1960s, 1980s and 1990s comparing to the initial breeding period before the 1960s (Table 3).

\section{Population Structure}

Population stratification for all 204 peach genotypes representatives of the Brazilian peach breeding germplasm were analyzed by successively increasing the number of subpopulations $(\mathrm{K})$ from 1 to 10 , with $\mathrm{K}=2$ followed by $\mathrm{K}=3$ having the highest 
delta $K(\Delta K)$ values using the Evanno method (EVANNO et al., 2005).

CLUMPP alignment on the outcomes of 20 independent replicates for $\mathrm{K}=2$, showed a similarity of $99 \%$, indicating that the assignment of accessions to the subpopulation was well correlated among runs. Population stratification suggested a clear subdivision by correspondence with flesh type: melting (yellow bars) and non-melting flesh cultivars/ selections (red bars) (Figure 1, $\mathrm{K}=2$ ).

Genotypes were assigned to a population if its membership coefficient was $\geq 80 \%$. Therefore, for all peach germplasm analyzed, 96 accessions were clustered into melting subpopulation, including peach cultivars for fresh consumption, nectarines with melting flesh, flat peach selections and three of the founding clones used in the breeding program ('Delicioso', 'Interlúdio' and 'Sunhigh'), while 66 accessions grouped with non-melting subpopulation, mainly including peach cultivars for canning, nectarines with non-melting flesh and three founder varieties ('Abóbora', 'Aldrighi', and 'Cristal-Taquari').

Considering $\mathrm{K}=2$, the remaining 42 accessions could not be assigned under the $80 \%$ membership coefficient criteria and were considered to be unstructured suggesting allele sharing. Mainly accessions clustered within this admixed group are cultivars with dual purpose (fresh market and canning) as 'Eldorado', 'Leonense', 'Maciel' and 'Riograndense', also comprises genotypes that have one or more of this dual purpose cultivars as parents or that present crosses between melting $\mathrm{x}$ non-melting cultivars in the genetic background. Ten of the 33 nectarines analyzed in this study and two founder varieties, 'Edmundo Perret' (canning peach) and 'Panamint' (the only founding clone of nectarine genotyped in this study), were also included in this admixture group. A clear agreement between population stratification at $\mathrm{K}=2$ and genetic diversity can be visualized with the PCoA analysis that also shows the relative close relationships between clusters obtained by STRUCTURE (Figure 2).

With increasing $\mathrm{K}$ to three subpopulations, the non-melting flesh group remained almost invariable (in red, Figure $1 \mathrm{~K}=3$ ), whereas the cluster of melting accessions split into two subpopulations, one principally melting flesh peaches (in yellow) and the other, a more diverse cluster composed mainly by nectarines (20 accessions of the total 33 nectarines analyzed), peach germplasm introductions from USA, Japan, Mexico and Bolivia, and advanced selections that have introductions as one of the parents. Moving to $\mathrm{K}=3$, the percentage of admixed accessions also increased, suggesting a more complex structure than with $\mathrm{K}=2$. No additional major subpopulations were observed with other $\mathrm{K}$ values.

Similar results associating genetic structure with fruit characteristics were also reported before by other authors (ARANZANA et al., 2010; LI et al., 2013; CHAVEZ et al., 2014) analyzing peach germplasm

Aranzana et al. (2010) identified three main groups: melting flesh peaches, melting flesh nectarines, and non-melting cultivars. Corroborating with the results of this study, these same authors with $\mathrm{K}=2$ detected a subdivision between melting and non-melting cultivars. Moving to $\mathrm{K}=3$, the cluster of melting cultivars split into peaches and nectarines. In our study it was not detected clear genetic evidence for nectarine vs. peach, but moving to $\mathrm{K}=3$, melting cultivars also split into peaches and nectarines, with the more diverse subpopulation being the one that groups most of the nectarines, while for those authors the non-melting subpopulation was considered the most diverse.

The Brazilian peach breeding program does not maintain separate breeding efforts for peaches and nectarines, this could explain why the founding clone nectarine variety 'Panamint' grouped together with the melting peach founders 'Interlúdio' and 'Sunhigh', when considered the subdivision of the germplasm into three subpopulations $(\mathrm{K}=3)$. However, only the founder variety 'Delicioso', the main cultivar used to develop melting flesh peach for fresh consumption, grouped with the melting subpopulation. The same was observed with the nonmelting founder varieties 'Abóbora' and 'Aldrighi' that cluster together in non-melting subpopulation, showing that different genetic resources were used in order to develop peach for fresh consumption and canning purposes in early breeding times. This may also be due to the longest period of breeding for melting and non-melting peach cultivars, with most of agronomic and fruit quality traits economically important already fixed, thus crosses are realized mainly between genotypes belonging to the same subgroup.

Li et al. (2013) assigned accessions to three subpopulations: Oriental, Occidental, and Landraces. The Occidental breeding subpopulation was subdivided into nectarine and peach subpopulations and Oriental subpopulation into ' $\mathrm{Yu} \mathrm{Lu}$ ' and 'Hakuho', were 'Yu Lu' derived cultivars include mostly accessions from Zhejiang Province and 'Hakuho' grouped Japanese cultivars or pedigreeassociated with 'Hakuho' high-chill Japanese cultivar. Three main groups were also identified 
by Chavez et al. (2014) in UF peach germplasm: outgroups and landrace germplasm, melting cultivars, and non-melting cultivars.

The principal coordinate analysis (PCoA) was used as a second approach to detect population structure. Once again the same subpopulations were identified as before with the Bayesian analysis. PCoA plot using all 204 peach genotypes is showed in Figure 2. In the PCoA, it is obvious that the primary axis separates the accessions based on the peach flesh type (melting and non-melting). It is observed that genetic variability is greater in the melting subpopulation. This difference between melting and non-melting subpopulations is due their genetic background. At the beginning of the program, breeding of melting peach cultivars used as basis several introductions from different countries and breeding programs, whereas the non-melting peach breeding efforts used mainly local varieties. Thus, the gene pool to select genotypes for processing purpose was probably smaller than the gene pool available to select peaches for fresh consumption. Also, it may contribute the fact that, worldwide, the number of peach breeding programs for processing purpose are only a few compared to peach breeding programs aiming melting peaches for fresh consumption. Thus, the source of germplasm exchange is limited. In the development of non-melting peaches for both the processing and fresh markets located in low chill zones, the longest running program is the nonmelting Embrapa peach program, in Brazil. Later, breeding efforts in Mexico were initiated. It should be noted that fresh market cultivars with non-melting flesh have been used for centuries in Latin America and Spain (BYRNE, 2005b). This approach has more recently been promoted in U.S by the Florida's fruit breeding program focused on non-melting texture peaches for fresh market.

In our study majority of the cultivars introduced from North America breeding programs were structured in the melting subpopulation suggesting a common gene pool. These results are in agreement, considering the active exchange of germplasm between the breeding programs of these two countries and the use of North American cultivars in Embrapa peach breeding program.

We also observed that the genetic diversity does not appear to have decreased analyzing allele frequencies grouping cultivars by decades of release. Among the germplasm present in this collection are a wide range of local peach cultivars, North American cultivars and germplasm introgressed from other countries indicating continuous enrichment of the breeding pool. The distribution of the founders in the three dimensions graph (Figure 2), suggests that founder varieties are still a direct source of current peach variability for breeding and release of new cultivars.

As the population structure is considered strong within melting and non-melting flesh genotypes, correction for population stratification will be necessary in order to preclude false positives in association studies. This research is a first step and a reference to choose genotypes for association mapping studies and enable marker assisted selection in peach breeding. 
TABLE 1- Cultivars and advanced selections of peach breeding germplasm, breeding period of cultivars released by the Embrapa breeding program and fruit characteristics.

\begin{tabular}{|c|c|c|c|c|c|c|c|}
\hline ID & Cultivar & Decade $^{a}$ & Fruit trait $^{\mathrm{b}}$ & ID & Cultivar & Decade $^{a}$ & Fruit trait ${ }^{b}$ \\
\hline 1 & Abóbora & Pre-1960s & PYNRC & 44 & Coral 2 & $1980 \mathrm{~s}$ & PWMRC \\
\hline 2 & Ágata & $1970 \mathrm{~s}$ & PYNRC & 45 & Cristal-taquari & Pre-1960s & PWNRC \\
\hline 3 & Aldrighi & Pre-1960s & PYNRC & 46 & Delicioso & Pre-1960s & PWMRF \\
\hline 4 & Alpes & $1980 \mathrm{~s}$ & PYNRC & 47 & Della Nona & $1990 \mathrm{~s}$ & PWMRF \\
\hline 5 & Amarillo & - & N??RS & 48 & Diamante & $1970 \mathrm{~s}$ & PYNRC \\
\hline 6 & Anita & $1990 \mathrm{~s}$ & NWMRC & 49 & Dulce & $1990 \mathrm{~s}$ & NWMRS \\
\hline 7 & Apote & - & P?NR? & 50 & Edmundo Perret & Pre-1960s & PWMRC \\
\hline 8 & Arlequim & - & PWMRF & 51 & Eldorado & $1980 \mathrm{~s}$ & PYNRC \\
\hline 9 & Atenas & $2000 \mathrm{~s}$ & PYNRC & 52 & Eragil & - & PYMRF \\
\hline 10 & Aurora 1 & - & PYNRC & 53 & Esmeralda & $1980 \mathrm{~s}$ & PYNRC \\
\hline 11 & Aurora 2 & - & PYMRC & 54 & Ewtrin & - & NWMRC \\
\hline 12 & Yellow Babcock* & - & PYNRC & 55 & Farrapos & $1960 \mathrm{~s}$ & PYNRC \\
\hline 13 & Barbosa & $1990 \mathrm{~s}$ & PWMRF & 56 & Flordabella & - & PYMRF \\
\hline 14 & Bolinha & $1980 \mathrm{~s}$ & PYNRC & 57 & Flordaglo & - & PWMRC \\
\hline 15 & BR1 & $1970 \mathrm{~s}$ & PWMRC & 58 & FlordaGrande & - & PYMRS \\
\hline 16 & BR3 & $1970 \mathrm{~s}$ & PWMRS & 59 & Flordaking & - & PYMRC \\
\hline 17 & Cai & $1960 \mathrm{~s}$ & PWMRC & 60 & Flordaprince & - & PYMRC \\
\hline 18 & Capdeboscq & $1960 \mathrm{~s}$ & PYNRC & 61 & Galaxy & - & PWMFC \\
\hline 19 & Cardeal & $1960 \mathrm{~s}$ & PYMRC & 62 & Gaúcho & $1980 \mathrm{~s}$ & PWMRS \\
\hline 20 & Regalo & $2000 \mathrm{~s}$ & PWMRC & 63 & \multicolumn{2}{|c|}{$\begin{array}{l}\text { Gaúcho de Porto } \\
\text { Alegre }\end{array}$} & PWMRS \\
\hline 21 & Cascata 805 & - & PWMRS & 64 & Gaudério & $1960 \mathrm{~s}$ & PYMRC \\
\hline 22 & Cascata 828 & - & PWMF? & 65 & Granada & $1990 \mathrm{~s}$ & PYNRC \\
\hline 23 & Cascata 838 & - & PYMFS & 66 & Interlúdio & Pre-1960s & PYMRS \\
\hline 24 & Fascínio & $2000 \mathrm{~s}$ & PWNRS & 67 & Jade & $1980 \mathrm{~s}$ & PYNRC \\
\hline 25 & Cascata 1303 & - & PYNRC & 68 & Josefina & - & NWMRF \\
\hline 26 & Cascata 1373 & - & PYNFC & 69 & Jubileu & $1990 \mathrm{~s}$ & PYNRC \\
\hline 27 & Cerrito & $1960 \mathrm{~s}$ & PYNRC & 70 & Kampai & $2000 \mathrm{~s}$ & PWMRS \\
\hline 28 & Chimarrita & $1980 \mathrm{~s}$ & PWMRS & 71 & Leonense & $1990 \mathrm{~s}$ & PYNRC \\
\hline 29 & Chiripá & $1970 \mathrm{~s}$ & PWMRF & 72 & Libra & $2000 \mathrm{~s}$ & PYNRC \\
\hline 30 & Conserva 334 & - & PYNRC & 73 & Linda & $1980 \mathrm{~s}$ & NYMRC \\
\hline 31 & Conserva 594 & - & PYNRC & 74 & Lord & $1970 \mathrm{~s}$ & PYNRC \\
\hline 32 & Conserva 672 & - & PYNRC & 75 & Maciel & $1990 \mathrm{~s}$ & PYNRC \\
\hline 33 & Conserva 930 & - & PYNRC & 76 & Madrugador & $1960 \mathrm{~s}$ & PYNRC \\
\hline 34 & Conserva 947 & - & PYNRC & 77 & Magno & $1970 \mathrm{~s}$ & PYNRC \\
\hline 35 & Conserva 1566 & - & PYNR? & 78 & Mara & $1990 \mathrm{~s}$ & NYMRS \\
\hline 36 & Conserva 1578 & - & PYNRC & 79 & Marli & $1980 \mathrm{~s}$ & PWMRS \\
\hline 37 & Conserva 1596 & - & PYNRC & 80 & Minuano & - & PYMRS \\
\hline 38 & Conserva 1600 & - & PYNRC & 81 & Mollares Hierro & - & PWMRF \\
\hline 39 & Conserva 1612 & - & PYNRC & 82 & Morro Redondo & $1960 \mathrm{~s}$ & PYNRC \\
\hline 40 & Conserva 1666 & - & PYNRC & 83 & Natal & - & PWMRC \\
\hline 41 & Conserva 1798 & - & PYNRC & 84 & Necta 468 & - & NWMRC \\
\hline 42 & Convênio & $1960 \mathrm{~s}$ & PYNRC & 85 & Necta 480 & - & NYNRC \\
\hline 43 & Coral & $1960 \mathrm{~s}$ & PWMRS & 86 & Necta 496 & - & NWMRC \\
\hline
\end{tabular}

continued 


\begin{tabular}{|c|c|c|c|c|c|c|c|}
\hline 87 & Necta 511 & - & NYNRC & 132 & Bonão & $2000 \mathrm{~s}$ & PYNRC \\
\hline 88 & Necta 512 & - & NYNRC & 133 & c-2006-198-48 & - & ????? \\
\hline 89 & Necta 528 & - & NWNRS & 134 & $c-2006-201-2$ & - & ????? \\
\hline 90 & Necta 532 & - & NY?RF & 135 & c-2006-201-9 & - & ????? \\
\hline 91 & Okinawa & - & PWMRF & 136 & Carapuça & $1960 \mathrm{~s}$ & PYMRS \\
\hline 92 & Olímpia & $2000 \mathrm{~s}$ & PYNRC & 137 & Cascata 349 & - & PYMRS \\
\hline 93 & Ônix & $1980 \mathrm{~s}$ & PYNRC & 138 & Cascata 700 & - & PYMRC \\
\hline 94 & Pampeano & $1990 \mathrm{~s}$ & PWMRS & 139 & Cascata 727 & - & PWNRC \\
\hline 95 & Panamint & Pre-1960s & NYMRF & 140 & Cascata 1005 & - & PYNR? \\
\hline 96 & Pepita & $2000 \mathrm{~s}$ & PYNRC & 141 & Cascata 1015 & - & PYNR? \\
\hline 97 & $\begin{array}{l}\text { Pérola } \\
\text { de Itaquera }\end{array}$ & - & PWNRC & 142 & Cascata 1055 & - & PWNR? \\
\hline 98 & Pilcha & $1980 \mathrm{~s}$ & PYMRC & 143 & Cascata 1067 & - & PWNR? \\
\hline 99 & Piratini & $1960 \mathrm{~s}$ & PYNRC & 144 & Cascata 1423 & - & PWMRS \\
\hline 100 & Planalto & $1990 \mathrm{~s}$ & PWNRC & 145 & Cascata 1429 & - & PWMRS \\
\hline 101 & Precocinho & $1980 \mathrm{~s}$ & PYNRC & 146 & Cascata 1493 & - & PWNRC \\
\hline 102 & Premier & $1960 \mathrm{~s}$ & PWMRS & 147 & Cascata 1511 & - & PWMFC \\
\hline 103 & Princesa & $1960 \mathrm{~s}$ & PYMRS & 148 & Cascata 1513 & - & PWMRS \\
\hline 104 & Real & - & PYNRC & 149 & Cascata 1577 & - & PWMRS \\
\hline 105 & Riograndense & $1990 \mathrm{~s}$ & PYNRC & 150 & Cascata 1669 & - & PWMRS \\
\hline 106 & Rubimel & $2000 \mathrm{~s}$ & PYMRS & 151 & Chato 10 & - & PWMFF \\
\hline 107 & Safira & $1980 \mathrm{~s}$ & PYNRS & 152 & Chato 11 & - & PYMFC \\
\hline 108 & San Pedro & - & PYMRS & 153 & Chato 13 & - & PWMFF \\
\hline 109 & Santa Áurea & $2000 \mathrm{~s}$ & PYNRC & 154 & Chula & $1990 \mathrm{~s}$ & PWMRF \\
\hline 110 & Sentinela & $1980 \mathrm{~s}$ & PWMRC & 155 & Conserva 657 & - & PYNRC \\
\hline 111 & Sinuelo & $1970 \mathrm{~s}$ & PYMRS & 156 & Conserva 1127 & - & PYNRC \\
\hline 112 & Sulina & $1980 \mathrm{~s}$ & PWMRC & 157 & Conserva 1218 & - & PYNRC \\
\hline 113 & Sunblaze & - & NYMRS & 158 & Conserva 1278 & - & PYNRC \\
\hline 114 & Sunhigh & Pre-1960s & PYMRS & 159 & Conserva 1526 & - & PYNRC \\
\hline 115 & Sunmist & - & NWMRC & 160 & Conserva 1556 & - & PYNRC \\
\hline 116 & Taquari 80 & - & PWMRS & 161 & Conserva 1806 & - & PYNRC \\
\hline 117 & Tarumã & $1960 \mathrm{~s}$ & PYNRC & 162 & Conserva 1812 & - & PYNRC \\
\hline 118 & Topázio & $1970 \mathrm{~s}$ & PYNRC & 163 & Douradão & - & PYMRF \\
\hline 119 & Tropic Beauty & - & PYMRC & 164 & Dourado 2 & - & PYMRF \\
\hline 120 & Tropic Blush & - & PYNRC & 165 & Early Diamond & - & NYMRC \\
\hline 121 & Tropic Snow & - & PWMRS & 166 & Flor da star & - & PYMRC \\
\hline 122 & Turquesa & $1970 \mathrm{~s}$ & PYNRC & 167 & Granito & $1990 \mathrm{~s}$ & PYNRC \\
\hline 123 & Vanguarda & $1980 \mathrm{~s}$ & PYNRC & 168 & Ingo & - & PWMRF \\
\hline 124 & Alvorada & $1960 \mathrm{~s}$ & PYMRC & 169 & July Elberta & - & PYMR? \\
\hline 125 & Âmbar & $2000 \mathrm{~s}$ & PYNRC & 170 & La Feliciana & - & PYMRF \\
\hline 126 & Ametista & $1990 \mathrm{~s}$ & PYNRC & 171 & Lotus & - & NYMRF \\
\hline 127 & AztecGold & - & PYNRC & 172 & Maravilha & - & PWMRC \\
\hline 128 & Babygold 7 & - & PYNRC & 173 & Marfim & $1990 \mathrm{~s}$ & PWNRC \\
\hline 129 & Babygold 9 & - & P?NR? & 174 & Necta 422 & - & NYNRC \\
\hline 130 & Baronesa & $1960 \mathrm{~s}$ & PYMRS & 175 & Necta 466 & - & NYNRC \\
\hline 131 & Blancona & - & PWMRF & 176 & Necta 508 & - & NYMRS \\
\hline
\end{tabular}

continued 


\begin{tabular}{lllllll}
177 & Necta 529 & - & NYMRS & 191 Springcrest & - & PYMR? \\
178 & Necta 531 & - & NWMRS & 192 Suncoast & - & NYMRF \\
179 & Necta 543 & - & NWMRF & 193 Sunlite & - & NYMRS \\
180 & Necta 3973 & - & NWMRC & 194 Sunred & - & NYMRC \\
181 & Morena & - & NYMR? & 195 Super morena & - & NYMRS \\
182 & Nectared 5 & - & NYMRC & 196 Talismã & - & PWMRC \\
183 & Norman & - & PYMRF & 197 Taq 98 & - & PWMRC \\
184 & Piazito & - & PWMRS & 198Tsukuba & - & $? ? ? ?$ \\
185 & Rayon & - & PYMRC & 199Tx 1A 95 & - & PYMRC \\
186 & Rei Del Monte & - & PYMR? & 200 Tx 1A 100 & - & PYMR? \\
187 & Sel. Bolinha 9 & - & PYNRC & 201 Tx 1A 125 & - & PYMRC \\
188 & Sel. Bolinha 17 & - & PYNRC & 202 Tx 1A 150 & - & PYMRC \\
189 & Sel. Bolinha 25 & - & PYNRC & 203 Tx 2A 232 LWN & - & NWMRC \\
190 & Sel. Bolinha 26 & - & PYNRC & 204 Vila Nova & $1960 s$ & PYMRF \\
\hline
\end{tabular}

${ }^{\mathrm{a}}$ Decade $=$ Refers to the breeding period that the cultivar was released (only for cultivars released by the Embrapa Breeding Program) ${ }^{\mathrm{b}}$ Fruit traits are as follows $=$ First letter: $P$ peach, $N$ nectarine. Second letter: $W$ white, $Y$ yellow. Third letter: $N$ non-melting flesh, $M$ melting flesh. Fourth letter: $R$ round shape, $F$ flat shape. Fifth letter: $C$ clingstone, $S$ semi-cligstone, $F$ freestone

$?=$ No information available

TABLE 2- Summary statistics of variability calculated for the 10 SSR markers in 204 peach genotypes.

\begin{tabular}{|c|c|c|c|c|c|c|c|}
\hline SSR Marker & A & $\mathrm{Ae}$ & Ho & $\mathrm{He}$ & $F$ & $\mathrm{PIC}$ & $\mathrm{N}^{\circ} \#$ genotypes \\
\hline pchgms 3 & 7 & 2.10 & 0.34 & 0.52 & 0.35 & 0.50 & 19 \\
\hline ВРРСТ020 & 7 & 2.75 & 0.45 & 0.64 & 0.29 & 0.58 & 13 \\
\hline ВРРСТ002 & 7 & 1.98 & 0.35 & 0.50 & 0.30 & 0.45 & 14 \\
\hline ВРРСТ007 & 7 & 2.01 & 0.38 & 0.50 & 0.24 & 0.46 & 12 \\
\hline ВРРСТ015 & 14 & 3.58 & 0.62 & 0.72 & 0.14 & 0.70 & 36 \\
\hline ВРРСТ014 & 5 & 2.39 & 0.44 & 0.58 & 0.25 & 0.54 & 11 \\
\hline ВРРСТ017 & 9 & 4.95 & 0.59 & 0.80 & 0.27 & 0.77 & 27 \\
\hline UDP98-407 & 9 & 4.58 & 0.57 & 0.78 & 0.27 & 0.75 & 25 \\
\hline СРРСТ022 & 11 & 3.91 & 0.59 & 0.74 & 0.21 & 0.72 & 34 \\
\hline СРРСТ006 & 4 & 2.25 & 0.28 & 0.56 & 0.50 & 0.46 & 7 \\
\hline Average & 8 & 3.05 & 0.46 & 0.63 & 0.28 & 0.59 & 19.8 \\
\hline Total & 80 & 30.5 & - & - & - & - & 198 \\
\hline
\end{tabular}

$\mathrm{A}=$ number of observed alleles; $\mathrm{Ae}=$ effective number of alleles; $\mathrm{Ho}=$ observed heterozygosity; $\mathrm{He}=$ expected heterozygosity; $F$ $=$ Wright's fixation index; PIC = polymorphism information content. 
TABLE 3- Changes in allelic counts by breeding period using SSR markers to evaluate $P$. persica cultivars released by the Embrapa Peach Breeding Program.

\begin{tabular}{|c|c|c|c|c|c|c|c|c|}
\hline \multirow[b]{2}{*}{ SSR marker } & \multirow{2}{*}{$\begin{array}{l}\text { Total } \mathrm{n}^{\circ} \text { of } \\
\text { alleles }^{\mathrm{a}}\end{array}$} & \multirow{2}{*}{$\begin{array}{c}\mathrm{N}^{\circ} \text { of rare } \\
\text { alleles }\end{array}$} & \multicolumn{6}{|c|}{ Allelic counts by breeding period } \\
\hline & & & $\begin{array}{c}\text { Pre-1960s } \\
(8)^{\mathrm{c}}\end{array}$ & $\begin{array}{c}1960 \mathrm{~s} \\
(18)\end{array}$ & $\begin{array}{c}1970 \mathrm{~s} \\
(10)\end{array}$ & $\begin{array}{c}1980 \mathrm{~s} \\
(18)\end{array}$ & $\begin{array}{c}1990 \mathrm{~s} \\
(16)\end{array}$ & $\begin{array}{c}2000 \mathrm{~s} \\
(11)\end{array}$ \\
\hline pchgms3 & 6 & 2 & 3 & 4 & 4 & 6 & 5 & 4 \\
\hline ВРРСТ020 & 6 & 2 & 4 & 6 & 3 & 4 & 5 & 4 \\
\hline ВРРСТ002 & 6 & 3 & 3 & 6 & 3 & 5 & 4 & 3 \\
\hline ВРРСТ007 & 4 & 1 & 3 & 3 & 2 & 4 & 4 & 3 \\
\hline ВРРСТ015 & 9 & 4 & 7 & 7 & 6 & 7 & 8 & 5 \\
\hline ВРРСТ014 & 4 & 0 & 4 & 4 & 4 & 4 & 3 & 4 \\
\hline ВРРСТ017 & 8 & 3 & 6 & 6 & 6 & 7 & 6 & 7 \\
\hline UDP98-407 & 8 & 3 & 6 & 7 & 5 & 6 & 6 & 5 \\
\hline СРРСТ022 & 9 & 5 & 5 & 6 & 5 & 6 & 6 & 6 \\
\hline СРРСТ006 & 4 & 2 & 3 & 2 & 2 & 4 & 3 & 2 \\
\hline Observed total & 64 & 25 & 44 & 51 & 40 & 53 & 50 & 43 \\
\hline Observed lost ${ }^{\mathrm{d}}$ & & & & 5 & 7 & 3 & 5 & 8 \\
\hline Observed gain $^{\mathrm{e}}$ & & & & 12 & 3 & 12 & 11 & 7 \\
\hline
\end{tabular}

${ }^{a}$ Total number of alleles in 81 peach cultivars released by the Embrapa Breeding Program including eight founder varieties.

${ }^{\mathrm{b}}$ Refers to alleles present at a frequency $<0.05$.

${ }^{\mathrm{c}}$ Numbers in parenthesis indicate the total number of cultivars analyzed in a given period

${ }^{d}$ Number of alleles absent in cultivars of a given period that were present in the founders (Pre-1960s).

${ }^{\mathrm{e}}$ Number of alleles present in cultivars of a given period that were absent in the founders (Pre-1960s).

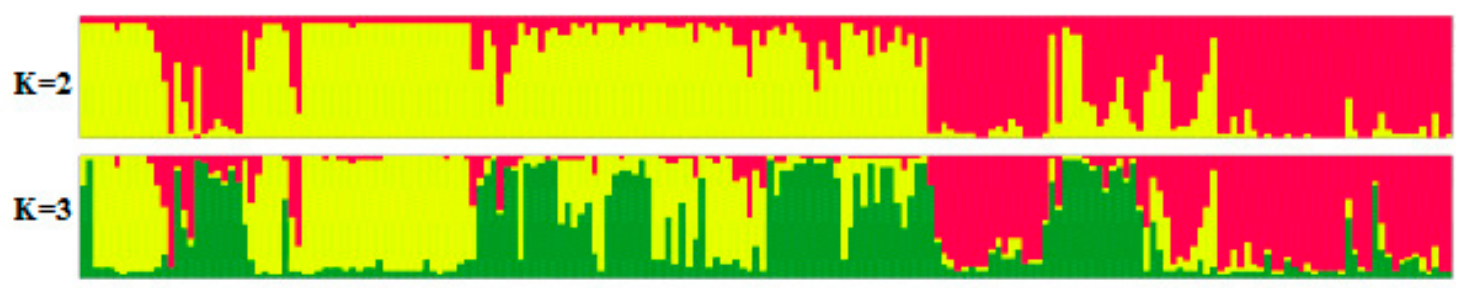

FIGURE 1- Population stratification of 204 peach cultivars based on Bayesian clustering approach. For $\mathrm{K}=2$, accessions in yellow indicates melting peach subpopulation, accessions in red indicates non-melting peach subpopulation. For $\mathrm{K}=3$, each color refers to a different subpopulation inferred by STRUCTURE analysis. 


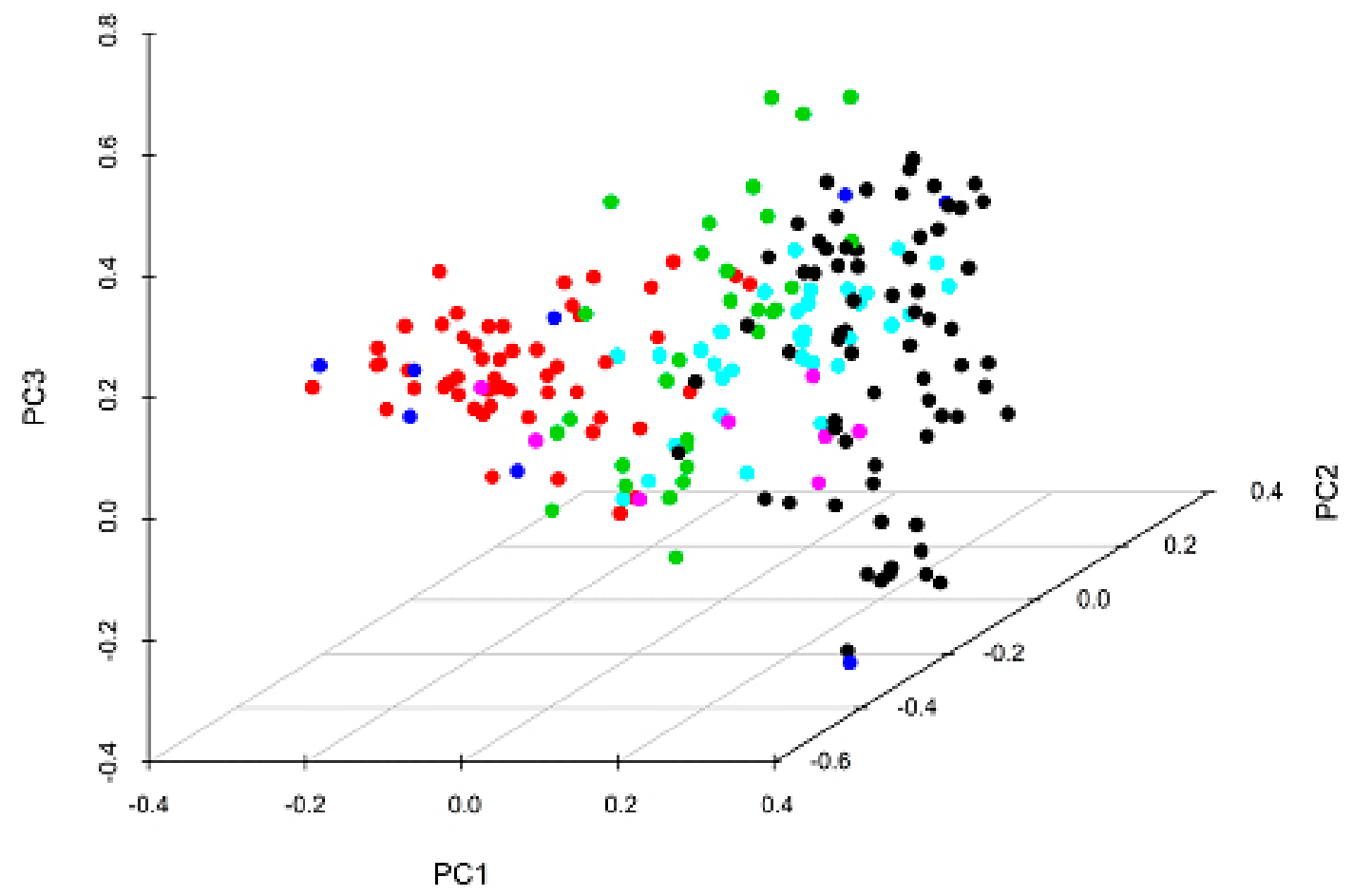

FIGURE 2-Genetic relationships between the 204 P. persica genotypes visualized using a principal coordinate analysis (PCoA). The individuals are coloured with respect to their subpopulations inferred by STRUCTURE analysis (membership coefficient $\geq 80 \%$ ): black indicates melting peach, red indicates non-melting peach, green indicates unstructured individuals (admixture), blue represents the founder varieties. The light blue and pink color represent the overlaid with fruit morphology traits, nectarines dispersion and flat peaches respectively. The first, second and third principal coordinates account for $17.62 \%, 10.24 \%$ and $7.52 \%$ of the total variation, respectively.

\section{CONCLUSIONS}

The genotypic information described here demonstrates a high level of genetic diversity available in Embrapa germplasm collection to be exploited for breeding. The both ways to investigate population stratification indicate strong population structure between melting and non-melting flesh genotypes. These results are essential in understanding the genomic relationships among the different peach genotypes and a very important tool for adjusting association tests. Future studies will include SNP discovery and genotyping to search for markers associated with valuable traits in peach.

\section{ACKNOWLEDGMENTS}

This work was supported by funds from the Project "Melhoramento genético de pessegueiro, nectarineira e ameixeira para adaptação às condições brasileiras" $\mathrm{N}^{\circ}$ 562400/2010-9 granted by Capes/ MTC/ CNPq - REPENSA. 


\section{REFERENCES}

ANDERSON, N. Diversity of low chill peaches ( Prunus persica) from Asia, Brazil, Europe, and the USA. 2010. 82p. Thesis (M.S. Horticulture) Texas A\&M University, College Station, 2010.

ARANZANA, M.J.; ABBASSI, E.; HOWAD, W.; ARÚS, P. Genetic variation, population structure and linkage disequilibrium in peach commercial varieties. BMC Genetics, London, v.11, p.69, 2010.

ARANZANA, M.J.; CARBÓ, J.; ARÚS, P. Microsatellite variability in peach [Prunus persica (L.) Batsch]: cultivar identification, marker mutation, pedigree inferences and population structure. Theoretical and Applied Genetics, Berlin, v.106, p.1341-1352, 2003.

ARANZANA, M. J.; GARCÍA-MAS, J.; ARÚS, P. Development and variability analysis of microsatellite markers in peach. Plant Breeding, Berlin, v.121, p.87-92, 2002.

BIELENBERG, D.; GASIC, K.; CHAPARRO, J.X. An introduction to peach (Prunus persica). In: FOLTA, K.M.; GARDINER, S.E. (Ed.). Genetics and genomics of Rosaceae. Heidelberg: Springer, 2009. p.223-234.

BOUHADIDA, M.; MORENO, M.A.; GONZALO, M.J.; ALONSO, J. M.; GOGORCENA, Y. Genetic variability of introduced and local Spanish peach cultivars determined by SSR markers. Tree Genetics e Genomes, Heidelberg, v.7, p.257- 270, 2011.

BYRNE, D. H. Founding clones of low chilling fresh market peach germplasm developed in the USA and Brazil. Acta Horticulturae, Lauven, v.606, p.7-21, 2003.

BYRNE, D.H. Trends and progress of low-chill stone fruit breeding. In: GEORGE, A. P.; BOONPRABOB, U. (Ed.). Production technologies for low chill temperate fruits. Canberra: ACIAR 1, 2005a. p.512. (Technical Reports, 6)

BYRNE, D.H. Trends in stone fruit cultivar development. HortTechnology, Alexandria, v.15, n.3, p.494-500, 2005b.
BYRNE, D. H.; BACON, T. A. Founding clones of low-chill fresh market peach germplasm. Fruit Varieties Journal, University Park, v.53, p.162-171, 1999.

BYRNE, D.H.; RASEIRA, M.B.; BASSI, D.; PIAGNANI, M.C.; GASIC, K.; REIGHARD, G.L.; MORENO, M.A.; PÉREZ, S. Peach. In: BADENES, M.L.; BYRNE, D.H. (Ed.). Fruit breeding: handbook of plant breeding. New York: Springer Science+Business Media, 2012. p.505-569.

CAO, K.; WANG, L.; ZHU, G.; FANG, W.; CHEN, C.; LUO, J. Genetic diversity, linkage disequilibrium, and association mapping analyses of peach (Prunus persica) landraces in China. Tree Genetics e Genomes, Heidelberg, v.8, p.975-990, 2012.

CHAVEZ, D.J.; BECKMAN, T.G.; WERNER, D.J.; CHAPARRO, J.X. Genetic diversity in peach [Prunus persica (L.) Batsch] at the University of Florida: past, present and future. Tree Genetics e Genomes, Heidelberg, v.10, p.1399-1417, 2014.

CIPRIANI, G.; LOT, G.; HUANG, W.G.; MATARAZZO, M.T.; PETERLUNGER, E.; TESTOLIN, R. AC/GT and AG/CT microsatellite repeats in peach [Prunus persica (L) Batsch]: isolation, characterization and cross-species amplification in Prunus. Theoretical and Applied Genetics, Berlin, v.99, p.65-72, 1999.

DIRLEWANGER, E.; COSSON, P.; TAVAUD, M.; ARANZANA, M. J.; POIZAT, C.; ZANETTO, A.; ARÚS, P.; LAIGRET, F. Development of microsatellite markers in peach [Prunus persica $(\mathrm{L}$.) Batsch] and their use in genetic diversity analysis in peach and sweet cherry (Prunus avium L.). Theoretical and Applied Genetics, Berlin, v.105, p.127-138, 2002.

DIRLEWANGER, E.; GRAZIANO, E.; JOOBEUR, T.; GARRIGA-CALDERE, F.; COSSON, P.; HOWAD, W.; ARÚS, P. Comparative mapping and marker-assisted selection in Rosaceae fruit crops. Proceedings of the National Academy of Sciences of the United States of America, Washington, v.101, n.26, p.9891-9896, 2004. 
EARL, D.A.; VONHOLDT, B.M. Structure harvester: a website and program for visualizing Structure output and implementing the Evanno method. Conservation Genetics Resources, Netherlands, v.4, p.359-361, 2012.

EVANNO, G.; REGNAUT, S.; GOUDET, J. Detecting the number of clusters of individuals using the software STRUCTURE: a simulation study. Molecular Ecology, Oxford, v.14, n.8, p.2611-2620, 2005.

FAOSTAT. Crops. Rome: FAO, 2013. Disponível em: $\leq$ http://faostat3.fao.org/download/Q/QC/E $>$. Acesso em: 27 jun. 2016.

FAUST, M.; TIMON, B. Origin and dissemination of peach. Horticultural Reviews, New York, v.17, p.331-379, 1995.

FERREIRA, M. E.; GRATTAPAGLIA，D. Introdução ao uso de marcadores moleculares em análise genética. 3.ed. Brasília: Embrapa-Cenargen, 1998. 220p.

FONT I FORCADA, C.; ORAGUZIE, N.; IGARTUA, E.; MORENO, M.A.; GOGORCENA, Y. Population structure and marker-traid associations for pomological traits in peach and nectarine cultivars. Tree Genetics and Genomes, Heildeberg, v.9, p.331-349, 2013.

JAKOBSSON, M.; ROSENBERG, N.A. Clumpp: a cluster matching and permutation program for dealing with label switching and multimodality in analysis of population structure. Bioinformatics, Oxford, v.23, n.14, p.1801-1806, 2007.

LI, X.; MENG, X.; JIA, H.; YU, M.; MA, R.; WANG, L.; CAO, K.; SHEN, Z.; NIU, L.; TIAN, J.; CHEN, M.; XIE, M.; ARÚS, P.; GAO, Z.; ARANZANA, M.J. Peach genetic resources: diversity, population structure and linkage disequilibrium. BMC Genetics, London, v.14, p.84, 2013.

LIGGES, U.; MÄCHLER, M. Scatterplot3d - an R Package for Visualizing Multivariate Data. Journal of Statistical Software, Los Angeles, v.8, n.11, p.120, 2003.

LIU, K.; MUSE, S. V. PowerMarker: Integrated analysis environment for genetic marker data. Bioinformatics, Oxford, v.21, n.9, p.2128-2129, 2005.
MYLES, S.; PEIFFER, J.; BROWN, P. J.; ERSOZ, E. S.; ZHANG, Z. W.; COSTICH, D. E.; BUCKLER, E. S. Association mapping: critical considerations shift from genotyping to experimental design. Plant Cell, Rockville, v.21, p.2194-2202, 2009.

PRICHARD, J.K.; STEPHENS, M.; DONNELLY, P. Inference of population structure using multilocus genotype data. Genetics, Austin, v.155, n.2, p.945959, 2000.

RASEIRA M.C.B.; BYRNE, D.H.; FRAZON, R.C. Pessegueiro: tradição e poesia.In: BARBIERI, R.L.; STUMPF, S.T. (Ed.). Origem e evolução de plantas cultivadas. Brasília: Embrapa Informação Tecnológica, 2008a. p.677-705.

RASEIRA, M.C.B.; CASTRO, C.M.; UENO, B. Intercâmbio e utilização de recursos genéticos de Prunóideas .In: MARIANTE, A.S; SAMPAIO, M.J.A.; INGLIS, M.C.V. (Org.). Informe nacional sobre a situação dos recursos fitogenéticos para a alimentação e a agricultura do Brasil. Brasília (DF): Embrapa, 2008b. p.54-56.

RASEIRA, M.C.B.; NAKASU, B.H. Pessegueiro. In: BRUCKNER, C.H. (Org.) Melhoramento de fruteiras de clima temperado. Viçosa: Editora UFV, 2002. p.89-126.

ROSENBERG, N.A. Distruct: a program for the graphical display of population structure. Molecular Ecology Notes, Oxford, v.4, p.137-138, 2004.

SOSINSKI, B.; GANNAVARAPU, M.; HAGER, L.D.; BECK, L.E.; KING, G.J.; RYDER, C.D.; RAJAPAKSE, S.; BAIRD, W.V.; BALLARD, R.E.; ABBOUTT, A.G. Characterization of microsatellite markers in peach [Prunus persica (L.) Batsch]. Theoretical and Applied Genetics, Berlin, v.101, p.421-428, 2000.

XIE, R.J.; LI, X.W.; CHAI, M.L.; SONG, L.J.; JIA, H.J.; WU, D.J.; CHEN, M.J.; CHEN, K.M.; ARANZANA, M.J.; GAO, Z.S. Evaluation of the genetic diversity of Asian peach accessions using a selected set of SSR markers. Scientia Horticulturae, Amsterdam, v.125, p.622-629, 2010.

YEH, F. C.; YANG, R. C.; BOYLE, T. B. J.; YE, $\mathrm{Z}$. H.; MAO, J. X. Popgene, the user-friendly shareware for population genetic analysis. Edmonton: University of Alberta, 1997. 